\author{
Roma Sendyka \\ Uniwersytet Jagielloński, Wydział Polonistyki \\ orcid.org/0000-0001-7647-2002 \\ roma.sendyka@uj.edu.pl
}

\title{
Niewinni winni. Strategie bezpieczeństwa mnemonicznego w kraju po Zagładzie
}

\author{
Opowieść o niewinności. Kategoria świadka Zagłady w kulturze polskiej \\ (1942-2015), red. Maryla Hopfinger i Tomasz Żukowski, Warszawa: Insty- \\ tut Badań Literackich PAN, 2018, 581 s.
}

Lata czterdzieste. Początki polskiej narracji o Zagładzie, red. Maryla Hopfinger i Tomasz Żukowski, Warszawa: Instytut Badań Literackich PAN, 2019, 299 s.

W kwietniu 2019 r. wybuchła w Polsce dyskusja wokół pruchnickiego okołowielkanocnego zwyczaju zwanego sądem nad Judaszem - praktyki czynnej przemocy na kukle Żyda. Zwyczaj ten pozostawał dotąd obecny w horyzoncie uwagi specjalistów: etnografów i regionalistów. Stanowiska przekonujące a to o neutralnym charakterze obrzędu, a to o jawnie antysemickiej motywacji wymierzania kary in effigie wyznaczyły granice i punkty orientacyjne wspólnotowego forum, na którym dziś odbywa się dyskusja o polskości i antysemityzmie. W to właśnie miejsce zostało skierowane ostrze krytyki zespołu pracującego od 2015 r. pod kierunkiem Maryli Hopfinger. Tomy zbiorowe Opowieść o niewinności. Kategoria świadka Zagłady w kulturze polskiej (1942-2015) i Lata czterdzieste. Poczatki polskiej narracji o Zagładzie docierały do publiczności nieomal równolegle z toczącym się sporem, przynosząc trafne diagnozy co do jego zasadniczych przyczyn. To, że wyniki badań udostępniono w tak stosownym momencie, bezpośrednio wskazuje na wyjątkowo celną hipotezę, która przed kilkoma laty poprzedziła sformułowanie pytań badawczych.

Publikacje trafiły do rąk czytelników zarazem w roku, który obchodami rocznicy wybuchu drugiej wojny światowej otworzył dziewiątą dekadę badań okupacyjnego doświadczenia ludności Polski. Dyskurs o przeszłości, odnowiony gwałtownym poruszeniem 1985 (Shoah Claude'a Lanzmanna) i 1987 r. (dyskusja wokół eseju Jana Błońskiego) oraz wstrząsem w roku 2000 (spory wokół Sąsiadów Jana Tomasza Grossa), znajduje w wystąpieniach zebranych przez Marylę Hopfinger i Tomasza Żukowskiego istotne przedłużenie. Wydane przez 
Instytut Badań Literackich PAN tomy o rodzimych narracjach na temat relacji polsko-żydowskich podtrzymują rewidujący tradycję nurt w polskiej humanistyce. Centralnym pytaniem o sile autentycznego zdumienia, które nadaje energię poszczególnym artykułom, jest kwestia mająca fundamentalne znaczenie dla zrozumienia historii antysemityzmu w Polsce. Dlaczego - pytają autorzy tomów - inaczej niż to się stało na zachodzie Europy, uświadomienie społeczeństwu skali, efektów i przebiegu ludobójstwa, jakim był Holokaust, nie doprowadziło w naszym kraju do publicznej i trwałej dyskredytacji postaw rasistowskich? Dlaczego antysemityzm nie został jawnie i wspólnotowo odrzucony, skompromitowany i usunięty z puli akceptowalnych praktyk społecznych? Dlaczego bliska obserwacja efektów nienawiści rasowej nie wywołała wstrząsu egzystencjalnego uniemożliwiającego wykluczające postawy wobec ludzkiej odmienności? Dlaczego w końcu towarzyszenie masowemu mordowaniu nie doprowadziło do ostracyzmu i rozliczeń czynnych uczestników tego procesu spośród polskiej społeczności ani do urealnienia opowieści o wojennej przeszłości społeczeństwa, a więc i o jego współcześnie prezentowanej tożsamości? „Nasza kultura nie wypracowała i nie dostarczyła wzorów tolerancji, obrony i akceptacji «Innego»" - pytania stają się stwierdzeniem o wadze oskarżenia ${ }^{1}$.

Autorzy i autorki tekstów (Aránzazu Calderón Puerta, Katarzyna Chmielewska, Helena Datner, Maryla Hopfinger, Elżbieta Janicka, Ewa Koźmińska-Frejlak, Wojciech Wilczyk, Anna Zawadzka, Tomasz Żukowski) realizowali zadania projektu „Wobec Zagłady - w stronę demitologizacji kategorii opisu. Kategoria «obojętni świadkowie»”. Jego częścią było seminarium „Kategorie opisu Zagłady w Polsce" prowadzone w Pracowni Współczesnej Literatury i Komunikacji Społecznej IBL PAN, podczas którego krytycznie przyglądano się figurze świadka, jaką dziś dziedziczymy po dziesięcioleciach sprawozdawania czasu wojny². Prace badawcze prowadzono przy założeniu, że „świadek” to przede wszystkim skomplikowana konstrukcja dyskursywna, a nie wyłącznie empiryczny byt - historyczny aktor pola przemocy. Odniesienie do tradycji narratologicznej (w słowniku autorów pojawią się kategorie „narracji”, jej „ram” oraz pokrewne terminom narratologii, motywowane technologią wizualizowania, koncepcje „transfokatorów” i „konwerterów”), inspirowanej wystąpieniami raczej Haydena White'a i Jamesa E. Younga niż Tzvetana Todorova i Mieke Bal, pozwoliło śledzić powstanie i narastanie praktyk przesuwania akcentów, usuwania z pola widzenia, osłabiania znaczenia, usprawiedliwiania i ukrywania niewygodnych faktów z przeszłości, a więc rodzenia się swoistej, tutejszej „opowieści o niewinności", wraz z jej słownikiem oraz gramatyką. Stawką było jednak przede

\footnotetext{
${ }^{1}$ Maryla Hopfinger, Zamiast wstępu [w:] Zagłada w „Medalionach” Zofii Nałkowskiej. Tekst i konteksty, red. Tomasz Żukowski, Warszawa: Instytut Badań Literackich PAN, 2016, s. 24.

${ }^{2}$ Zob. opis na stronie: https://ibl.waw.pl/pl/o-instytucie/pracownie-i-zespoly/pracowniawspolczesnejliteraturyikomunikacjisp/seminarium-kategorie-opisu-zaglady-w-polsce-/ seminarium-kategorie-opisu-zaglady-w-polsce (dostęp 10 VII 2019 r.).
} 
wszystkim odsłonienie tego, co owa opowieść skryła. A mianowicie tego, że „głęboko zakorzeniony antysemityzm, istniejący długo przed wojną, nie tylko ułatwił przeprowadzenie Zagłady, ale również przyczynił się do jej wykonania”3.

Przedstawione wyniki są efektem pracy kulturoznawczej, czerpiącej z tradycji hermeneutyki tekstów kultury. W omawianych tomach znajdziemy inspirujące odczytania filmów, dokumentów, zdjęć, plakatów, okładek, reportaży, opowiadań i powieści. Badacze obserwowali wielomedialny dyskurs kilku dziesięcioleci dzielących nas od wojny, by uchwycić procesy i „opisać retoryczne wytwarzanie pozycji świadka, któremu towarzyszy selekcja faktów i zjawisk wchodzących do opowieści, budowanie kolektywnych aktorów wydarzeń i określanie granic reprezentacji (oddzielanie zjawisk reprezentatywnych od marginalnych, grup istotnych od nieważnych), tworzenie obrazu zachowań grupowych i towarzyszących im motywacji"4. Wybierane do analizy obiekty funkcjonowały jak dane w procesie indukcji - ustalane fakty stawały się przesłanką do uogólnienia, które mieściłoby się - jak to zostało zadeklarowane w przytoczonym cytacie już w obszarze nauk społecznych, diagnozując postawy wspólnotowe.

Za kontekst tego wystąpienia należy uznać rosnące w skali globalnej zainteresowanie kategorią „bystanders”. Wprawdzie relacje ludności nieżydowskiej do żydowskiej w krajach okupowanych lub podporządkowanych Trzeciej Rzeszy były wielokrotnie przedmiotem analizy w powojennych studiach socjohistorycznych, a pierwsze prace powstawały jeszcze w czasie wojny (por. Emanuel Ringelblum, Stosunki polsko-żydowskie w czasie drugiej wojny światowej. Uwagi i spostrzeżenia, 1943) ${ }^{5}$, a termin „bystander” pojawiał się okazjonalnie w pracach historyków ${ }^{6}$, to jednak dopiero wystąpienie Raula Hilberga (Perpetrators, Victims, Bystanders: The Jewish Catastrophe, 1933-1945, publikacja w 1992 r.) ${ }^{7}$, zainspirowane praktyką twórczą Claude'a Lanzmanna (Shoah, 1985), zainicjowało nowy nurt w globalnych studiach nad Holokaustem. Jego rozwój wpływa obecnie na partykularne pola badawcze społeczeństw, które odnawiają własne „bilateralne” studia nad relacjami między ofiarami Zagłady a lokalnymi społecz-

${ }^{3}$ Maryla Hopfinger, Lata czterdzieste. Wprowadzenie [w:] Lata czterdzieste. Poczq̨tki polskiej narracji o Zagładzie, red. Maryla Hopfinger, Tomasz Żukowski, Warszawa: Instytut Badań Literackich PAN, 2019, s. 8.

${ }^{4}$ Zob. opis seminarium „Kategorie opisu Zagłady w Polsce” - por. przypis 2.

${ }^{5}$ Emanuel Ringelblum, Stosunki polsko-żydowskie w czasie drugiej wojny światowej. Uwagi i spostrzeżenia, oprac. Artur Eisenbach, Warszawa: Czytelnik, 1988 [nowe wydanie: Archiwum Ringelbluma. Konspiracyjne Archiwum Getta Warszawy, t. 29a: Pisma Emanuela Ringelbluma z bunkra, oprac. Eleonora Bergman, Tadeusz Epsztein, Magdalena Siek, Warszawa: ŻIH, 2018].

${ }^{6}$ Zob. Bystanders to the Holocaust, red. Michael R. Marrus, t. 1-3, Westport-London: Meckler, 1989 (seria „The Nazi Holocaust”, t. 8).

${ }^{7}$ Raul Hilberg, Perpetrators, Victims, Bystanders: The Jewish Catastrophe, 1933-1945, New York: Aaron Asher Books, 1992; wyd. polskie: Sprawcy, ofiary, świadkowie. Zagłada Żydów 1933-1945, tłum. Jerzy Giebułtowski, Warszawa: Centrum Badań nad Zagładą Żydów i Wydawnictwo Cyklady, 2007. 
nościami, reorientując je dzięki narzędziom, terminologii i nowym kontekstom umożliwiającym studia porównawcze.

Gdyby obserwacji poddać scenę polską, tłem teoretycznym publikacji pod redakcją Maryli Hopfinger i Tomasza Żukowskiego jest trwająca przynajmniej od 2008 r. dyskusja wywołana krytyką utożsamienia zarówno w tutejszej praktyce badawczej, jak i w popularnym uzusie terminu i funkcji „bystander” z kategorią „świadka”.Źródło tej identyfikacji nie zostało jeszcze ustalone, choć należy go zapewne poszukiwać (jak czyni to np. Katarzyna Chmielewska) w tużpowojennym języku jurystycznym, przenikającym z procesów sądowych do prasy i obiegu ogólnego. Impulsem do współczesnej dyskusji była decyzja tłumacza tomu Hilberga Jerzego Giebułtowskiego, który przełożył bystanders jako „świadków”, co początkowo zostało przyjęte bez protestów ${ }^{8}$, choć Elżbieta Janicka już w $2008 \mathrm{r}$. w recenzji Strachu Jana Tomasza Grossa kwestionowała stawianie znaku równości między pozycją polskiej ludności a tzw. miejscem świadka ${ }^{9}$, zwracając uwagę na konotowaną $w$ terminie sugestię oddzielania i niezaangażowania, sprzeczną z odsłanianymi, przede wszystkim dzięki publikacjom Centrum Badań nad Zagładą Żydów, faktycznymi cechami postaw społeczności dopełniającej pole przemocy ${ }^{10}$. Wątpliwości zgłosił również Jan Tomasz Gross w tekście Sprawcy, ofiary i inni z 2014 r., wskazując na błędne założenie nomenklaturowej równowartości: „W języku polskim słowo «bystanders» nie ma dobrego ekwiwalentu” - pisał $^{11}$.

Proces badania tekstów kultury, w których centralnie lub rezydualnie, jawnie lub w sposób zawoalowany artyści ujawnili nieheroiczną i niechlubną postawę polskiej ludności wobec potrzebujących pomocy Żydów, członkowie zespołu podsumowali, przygotowując nie dwie (wymienione w nagłówku), lecz trzy zbiorowe publikacje ${ }^{12}$. Poza wspomnianymi dwoma tomami do pełnego przed-

\footnotetext{
${ }^{8}$ Tom Hilberga nie skupił większej uwagi krytyki w Polsce. Jedną z nielicznych recenzji w Polsce napisał Sławomir Buryła (idem, Z perspektywy sprawców, ofiar i świadków, „Znak” 2007, nr 11).

${ }^{9}$ Elżbieta Janicka, Mord rytualny z aryjskiego paragrafu: o książce Jana Tomasza Grossa „Strach. Antysemityzm w Polsce tuż po wojnie. Historia moralnej zapaści”, „Kultura i Społeczeństwo" 2008, nr 2, s. 238.

${ }^{10}$ Stanowisko to zostało rozwinięte w wystąpieniach Elżbiety Janickiej i Tomasza Żukowskiego (eidem, Ci nie sq z ojczyzny naszej, „Gazeta Wyborcza”, 7 V 2012, http://wyborcza.pl/ magazyn/1,124059,11677718,Ci_nie_sa_z_ojczyzny_naszej.html, dostęp 10 VII 2019 r.).

${ }^{11}$ Jan Tomasz Gross, Sprawcy, ofiary i inni, „Zagłada Żydów. Studia i Materiały” 2014, nr 10, t. 2, s. 885 .

${ }^{12}$ Do pełni obrazu tego projektu trzeba jeszcze wspomnieć o indywidualnym wystąpieniu Tomasza Żukowskiego, książce powstałej w ramach tego samego projektu badawczego. Tom Wielki retusz. Jak zapomnieliśmy, że Polacy zabijali Żydów (Warszawa: Wielka Litera, 2018) zawiera pięć analiz dostrzeganych przez autora w polskim uogólnionym dyskursie o polsko-żydowskiej przeszłości strategii unikowych i uśmierzających (m.in. akcentowania straumatyzowania polskiego społeczeństwa, jego bohaterskiego zaangażowania w akcje ratowania, odmowy kolaboracji). Wszystkie cztery tomy łączą podobne założenia badawcze, odnoszenie
} 
stawienia zaproponowanych tez koniecznie trzeba przywołać jeszcze pracę pod redakcją Tomasza Żukowskiego z 2016 r., zatytułowaną Zagłada w „Medalionach” Zofii Nałkowskiej. Tekst i konteksty ${ }^{13}$. Trzy poseminaryjne tomy zbiorowe są efektem interesującej strategii przyjmowania odmiennych ujęć perspektywicznych wobec tego samego problemu. Metaforycznie można oddać ten pomysł, mówiąc o manipulowaniu ogniskową: rozpoczęto od obserwacji wybranego paradygmatycznego tekstu podnoszącego kwestie wojennych zbrodni i odpowiedzialności. Jego analiza przebiegała w maksymalnym zbliżeniu (zoom-in w rok 1946, kiedy to wydano Medaliony), metodą bliskiego czytania, w którym odsłaniały się frazy i sceny chętnie pomijane we wspólnotowym odbiorze tego tekstu-pomnika. Następnie punkt obserwacji został oddalony (zoom-out, pozwalający obserwować bardzo długi okres 1942-2015), tak by możliwe było ujęcie historyzujące, rekonstruujące proces; $w$ orbitę badawczą dostały się dzięki temu zabiegowi liczne teksty i wystąpienia z kolejnych powojennych dekad, czasem powszechnie znane, czasem na dobre zapomniane. Ten gest pozwolił uchwycić przemiany, a raczej łagodzące retusze narracji o stosunkach polsko-żydowskich. Ostatnim ruchem byłoby ujęcie pośrednie - umożliwiające szczegółową obserwację zjawisk z jednej, lecz kluczowej, dekady (tom Lata czterdzieste... odnosi się do druków z lat 1940-1951).

W tomie realizującym pierwszą z wymienionych strategii badaniom podlegał tekst zwyczajowo czytany jako oskarżenie zbrodni hitlerowskich dokonanych na Żydach. Autorzy interwencyjnych artykułów (Aránzazu Calderon Puerta, Katarzyna Chmielewska, Maryla Hopfinger, Bożena Keff, Wojciech Wilczyk, Tomasz Żukowski) akcentują wbrew tej lekturowej tradycji te fragmenty opowiadań Nałkowskiej, które są opisem stanowisk i postaw nieżydowskich Polaków. Rozmaite podejmowane przez badaczy strategie krytyczne dobrze służą zamiarowi odsłonięcia procesu zanikania publicznej uwagi dla zorientowanej na „bystanders”

się do wspólnego zestawu analizowanych tekstów i lektur kontekstualizujących interpretacje. Wystąpienie Żukowskiego wyrasta z ustaleń seminarium i wspólnych odczytań zaprezentowanych $w$ tomach zbiorowych, jest w moim przekonaniu najpełniejszą i bodaj najciekawszą z serii publikacji. Sprzyja temu konsekwentna strategia analityczna, indywidualna, rozpoznawalna i zaangażowana dykcja, erudycja kulturowa pozwalająca budować odsyłacze do rozmaitych, różnomedialnych tekstów kultury i ciekawe odkrycia - autor co raz przywraca uwadze czytającego to, co niegdyś „zauważone, sproblematyzowane i zanalizowane”, zostało sprawnie „usunięte z horyzontu kultury” (s. 16). Żukowski dokonuje sprzyjającego - moim zdaniem - analizie przesunięcia metodologicznego: zamiast słabo uzasadnionej koncepcji „Wzorów kultury” rządzącej tomami zbiorowymi, wybiera „ramy pamięci wspólnotowej” Maurice'a Halbwachsa, odwołując się raczej do pamięcioznawstwa i psychoanalizy niż analizy strukturalnej i semiotyki (zob. wyjaśnienia metodologiczne zespołu na stronie: https://ibl. waw.pl/pl/o-instytucie/pracownie-i-zespoly/pracowniawspolczesnejliteraturyikomunikacjisp/seminarium-kategorie-opisu-zaglady-w-polsce-/seminarium-kategorie-opisu-zaglady-w-polsce, dostęp 10 VII 2019 r.).

${ }^{13}$ Zagłada w „Medalionach” Zofii Nałkowskiej. Tekst i konteksty, red. Tomasz Żukowski, Warszawa: Instytut Badań Literackich PAN, 2019, s. 333. 
części relacji pisarskiej z pracy w Głównej Komisji Badania Zbrodni Niemieckich w Polsce. Podstawowym narzędziem zastosowanym w tomie jest obserwacja recepcji Medalionów (teksty Tomasza Żukowskiego i Aránzazu Calderon Puerty), nie oznacza to jednak zamknięcia analiz w obszarze historii krytyki literackiej. Badana jest także lektura hipotekstu Nałkowskiej wyprowadzana z adaptacji filmowych (w reżyserii Andrzeja Brzozowskiego i Bogusławy Torskiej) czy wypowiedzi wizualnych: ilustracji i okładek proponowanych przez wydawców (artykuły Tomasza Żukowskiego i Bożeny Keff). Hermeneutyczna praca zespołu sięga też instalacji artystycznych, dla których wystąpienie Nałkowskiej jest zasadniczym, choć niekoniecznie jawnym intertekstem (artykuł Wojciecha Wilczyka o Kobiecie na torach Tadeusza Rolkego). Nowa, „Zagładowa”, a nie „humanistyczna" lektura Medalionów (próba Katarzyny Chmielewskiej) korzeni się w tekstach z epoki - do tomu dołączono faksymile jednej z Pieśni żałobnych getta Izabeli Gelbard (Czajki-Stachowicz), w którym to utworze mamy do czynienia z zapisem sceny przywołanej przez Nałkowską w Przy torze kolejowym.

W najobszerniejszej części „trylogii o niewinności świadków”, wydanej w odmiennej szacie graficznej Opowieści o niewinności..., wyróżnionej w ten sposób jako centralna wypowiedź zespołu, znalazły się teksty dotyczące kolejno okresu okupacji i każdej z powojennych dekad (od lat czterdziestych po aktualne dziesięciolecie). To niewątpliwie najbardziej dopracowany i precyzyjnie zaplanowany tom, przywracający do wspólnej dyskusji pominięte, zapomniane lub uciszone dzieła artystów próbujących po wojnie ujawniać polskie zaangażowanie w Zagładę. Buduje on dla całego projektu ważną poznawczo ramę historyczną, dodatkowo wzmocnioną przez Marylę Hopfinger, która w otwierającym artykule Wszyscy jesteśmy świadkami. Zamiast wstępu rekonstruuje dynamikę siedmiu dekad relacji polsko-żydowskich w spójnym kompendium przypominającym zdarzenia o największym ciężarze konsekwencji: począwszy od czasów Zagłady i powojennych pogromów po współczesność (bardzo niedawną: w finale omawiana jest nowelizacja ustawy o IPN z 2018 r.). Celem, jaki stawiają sobie autorzy, jest udzielenie odpowiedzi na serię otwartych, zasadniczych dla polskiej kultury i tożsamości, wciąż nierozwiązanych (a raczej pozornie rozwiązanych) kwestii: „Co znaczyło być świadkiem Zagłady w Polsce wtedy i przez mijające dekady do dzisiaj? Jak na to doświadczenie odpowiadają autorzy i odbiorcy, uczestnicy polskiej kultury? Czy i jaki wpływ na każdego z nas mogła/musiała mieć, miała/ma Zagłada?"14.

W tym tomie pojawia się ponadto najważniejszy, objaśniający stanowiska zespołu, tekst dotyczący nomenklatury i teorii „świadczenia”: Katarzyna Chmielewska w Konstruowaniu figury polskiego świadka podczas Zagłady wskazuje na deformującą poznanie historyczne kontaminację pozycji „świadka” i „bystan-

${ }^{14}$ Maryla Hopfinger, Wszyscy jesteśmy świadkami. Zamiast wstępu [w:] Opowieść o niewinności. Kategoria świadka Zagłady w kulturze polskiej (1942-2015), red. Maryla Hopfinger i Tomasz Żukowski, Warszawa: Instytut Badań Literackich PAN, 2018, s. 7. 
dera". Tekst jest zbudowany wokół pojęć teoretycznych (świadka, świadka moralnego, świadka w znaczeniu prawnym lub historycznym), ale o jego ważkości przesądza zwłaszcza część rekonstruująca "lata czterdzieste” i zachodzącą w tym czasie zmianę ramy pojęciowej. W tekście Narracje alternatywne wobec polityki pamięci. Lata czterdzieste Chmielewska rekonstruuje wojenne kultury pamięci dotyczące Zagłady - czyli obserwuje dyskurs afirmacyjno-łagodzący w momencie jego narodzin. Przeciwstawia mu próby przedstawienia doświadczenia żydowskiego, analizując m.in. teksty z tomu Martwa fala. Zbiór artykułów o antysemityzmie (1947, redakcja Stanisława Ryszarda Dobrowolskiego), publicystykę z łamów „Odrodzenia”, „Tygodnika Powszechnego”, „Kuźnicy” (okres 1945-1949), wystąpienia Czesława Miłosza, Ludwika Heringa, Jerzego Andrzejewskiego czy film Powrót, czyli ślepy tor w reżyserii Bořivoja Zemana, według scenariusza Adama Ważyka, zrealizowany pod kierownictwem literackim Tadeusza Borowskiego (z 1948, pokazany w 1991 r.).

Kolejnych siedem tekstów prezentuje analizy skoncentrowane na zjawiskach $\mathrm{z}$ okresu danego dziesięciolecia, $\mathrm{w}$ wymiarze chronologicznym tom jest bowiem pomyślany jako seria sond zapuszczanych w kolejne dekady - Polski wojennej i tużpowojennej, PRL, w końcu Rzeczypospolitej po 1989 r. Tomasz Żukowski zastanawia się, co liberalizacja reżimu po 1956 r. pozwoliła powiedzieć na temat stosunków polsko-żydowskich (analiza Pokolenia Andrzeja Wajdy z 1954 r., Samsona - powieści Kazimierza Brandysa i filmu w reżyserii Wajdy z 1961 r., odwilżowych Kolumbów. Rocznik 20 Romana Bratnego i serialu Janusza Morgensterna). Anna Zawadzka bada narracje „polsko-żydowskiego braterstwa”, analizując teksty z trzech dekad (od lat sześćdziesiątych po dziewięćdziesiąte). Krytyce zostają poddane: zbiór dokumentów i wypowiedzi Ten jest z ojczyzny mojej. Polacy z pomoca Żydom 1939-1945 w opracowaniu Władysława Bartoszewskiego i Zofii Lewinówny (1966), Rozmowy z katem Kazimierza Moczarskiego (1977), Zdążyć przez Panem Bogiem Hanny Krall (1977) oraz Poczq̨tek Andrzeja Szczypiorskiego (1986). Zawadzka nieufną lekturą śledzi dyskusje ze stereotypem polskiego antysemityzmu, fundacyjne dla „narracji o niewinności”. W następnym tekście tomu wysłuchuje pisarzy żydowskich, gdy ujawniają zachowania katolickiej większości. Obok autorów wielokrotnie przywoływanych w tomach przez wielu autorów (Maria Kann, Zofia Kossak-Szczucka, Jan Błoński, Kazimierz Wyka, Zofia Nałkowska, Jerzy Andrzejewski) pojawiają się więc kolejne głosy i nieczęsto cytowane teksty: Wielki Stefan Konecki Adolfa Rudnickiego (1948), Pusta woda Krystyny Żywulskiej (1963), Zapiski z martwego miasta Artura Sandauera (1963) i Żydowska wojna Henryka Grynberga (1965).

Dekadę lat osiemdziesiątych reprezentują teksty Biedni Polacy patrzq na getto Jana Błońskiego i „Ten jest z ojczyzny mojej..., ale go nie lubię Jana Tomasza Grossa, badane w kontrastującym ujęciu przez Tomasza Żukowskiego i Aránzazu Calderón Puertę. Umschlagplatz Jarosława Marka Rymkiewicza (1988) i nieco wcześniejsza Archeologia (1967), dokument Andrzeja Brzozowskiego to - zdaniem Żukowskiego - przejawy kultury, w których można dostrzec nowy proces 
pojawiania się „nostalgicznej pamięci”, egzemplifikowanej np. przez Weisera Dawidka Pawła Huellego z 1987 r., a pozwalającej na pozbawione ryzyka „odtwarzanie historii Zagłady, zbliżanie się do Żydów, wchodzenie z nimi w intymną relację" i „utożsamienie się z zamordowanymi” ${ }^{15}$. Gdy już wydaje się, że uładzona i niekonfliktowa wersja przeszłości wygrywa, na horyzoncie w kolejnych latach po przełomie 1989 r. pojawią się gesty rewizjonistyczne, kumulujące się w pełnym odwołań do poprzedników Pokłosiu (2012) w reżyserii Władysława Pasikowskiego (szczegółową analizę filmu proponuje Elżbieta Janicka). Zamykający tom artykuł Wojciecha Wilczyka przynosi natomiast ważną, w moim przekonaniu, propozycję alternatywnego tomu - który zamiast dokumentów tekstualnych, poddałby analizie wizualia. „Bystander” - czy nazwać go świadkiem, gapiem, obserwatorem, obserwatorem wtajemniczonym i zaangażowanym ${ }^{16}$ - jest definiowany przez swą zdolność wzrokowej rejestracji zachodzących wydarzeń. Analiza wizualna może przynieść zaskakujące wyniki ${ }^{17}$, zważywszy na to, że potrafi wypełniać pola „niewypowiadalnego”, umykające narracji, poddane represji i pochłonięte przez traumę. Wilczyk ostrzega jednak, że dostępne dokumenty wytworzone przez postronnych ${ }^{18}$ są nieliczne i często formalnie zależne od wizualizacji zrealizowanej niegdyś przez sprawców.

Tom Lata czterdzieste. Poczq̨tki polskiej narracji o Zagładzie dociera do odbiorców jako ostatni. Mapuje kluczowy czas: ten, w którym odbywa się Zagłada, i ten tuż po niej, gdy w warunkach radykalnych przemian rodzi się język, by o niej mówić. Obserwacja tego - zwrotnego, konstytutywnego w sensie historycznym, politycznym, etycznym i artystycznym - momentu wyłaniania się

${ }^{15}$ Tomasz Żukowski, Archeologia nostalgiczna i archeologia krytyczna [w:] ibidem, s. 396.

${ }^{16}$ Zob. Elżbieta Janicka, Pamięć przyswojona. Koncepcja polskiego doświadczenia zagłady Żydów jako traumy zbiorowej w świetle rewizji kategorii świadka, „Studia Litteraria Historica” 2014-2015, nr 3/4.

${ }^{17}$ Potencjał ewentualnej analizy wizualnej, wyzyskującej różnice znaczeniowe między obserwatorem, gapiem, widzem, osobą patrzącą, spoglądającą, podglądającą i widzącą, opisuję w tekście: Od obserwatorów do gapiów. Kategoria bystanders i analiza wizualna, „Teksty Drugie" 2018, nr 3, oraz w artykule Bystanders as Visual Subjects: Onlookers, Spectators, Observers, Gawkers, opublikowanym w: Probing the Limits of Categorization. The bystander in Holocaust history, red. Christina Morina, Krijn Thijs, New York: Bergham Books, 2019.

${ }^{18}$ Jako ekwiwalent angielskiego terminu bystander proponuję termin „postronny” w tekstach Poświadek, przeciw-postronny i (niczyja) trauma („Widok. Teorie i praktyki kultury wizualnej” 2017, nr 18) i Od świadków do postronnych. Kategoria „bystander” i analiza podmiotów uwikłanych ([w:] Świadek: jak się staje, czym jest?, red. Agnieszka Dauksza, Karolina Koprowska, Warszawa: Instytut Badań Literackich PAN, 2019). Stosujemy go w publikacji Nie-miejsca pamięci. Elementarz, wydanej w 2017 r. przez Ośrodek Badań nad Kulturami Pamięci UJ (red. Karina Jarzyńska, Maria Kobielska, Jakub Muchowski, Roma Sendyka, Aleksandra Szczepan), towarzyszącej projektowi badawczemu „Nieupamiętnione miejsca ludobójstwa”. W formie „postronny świadek” używa go Aleksandra Szczepan, jako „postronny” rozwija Karolina Koprowska w pracy Postronni? Zagłada w relacjach chłopskich świadków (Kraków: Universitas, 2018). 
nowej wspólnoty po czasie przemocy jest jednym z najpilniejszych zadań polskiej nauki, a stawką jest rozeznanie fundamentów tożsamości obecnego społeczeństwa. Skalę potrzebnych badań uzmysławiał Marcin Zaremba w Wielkiej trwodze (2012), zespół Maryli Hopfinger proponuje więc ważne uzupełnienie pola badawczego: przekrojowe ujęcie zjawisk kulturowych kluczowej dekady. Tu również działa metoda „wybranych przykładów”, otrzymujemy zatem kolejne miejscowe sondy w przeszłość, pozwalające jednak autorom na diagnozę o nieustannej gotowości do obrony pozytywnego autowizerunku społeczności „świadków”.

Ewa Koźmińska-Frejlak obserwuje kontrolowaną przez Niemców prasę i pojawiające się na jej łamach uwagi o getcie. Pozbawione empatii lub jawnie konfliktujące wypowiedzi są zestawione $\mathrm{z}$ apelami wolnej prasy podziemnej. Uważna lektura wystąpień Zofii Kossak-Szczuckiej, Antoniego Szymanowskiego i Marii Kann, w których w najogólniejszym ujęciu wzywają oni do udzielania pomocy Żydom, odsłania jednak wspólną część obu zespołów: po każdej ze stron barykady wciąż funkcjonują przedwojenne uprzedzenia. Przekrojowe teksty proponują także Anna Zawadzka (badająca m.in. pierwsze podręczniki szkolne) i Helena Datner (analizująca powojenną publicystykę krytykującą antysemityzm). Wojciech Wilczyk również przywołuje reportaż Szymanowskiego, ale najciekawszą część jego pracy stanowi komentarz dotyczący zdjęć z getta fotografa kolaboranta Mieczysława Bila-Bilażewskiego, odnalezionych niedawno w kolekcji zakupionej przez Muzeum Powstania Warszawskiego. Katarzyna Chmielewska proponuje uwspółcześnioną (zestawianą z ustaleniami Andrzeja Ledera i Marcina Zaremby) lekturę Życia na niby Kazimierza Wyki (zapiski z lat 1939-1945, wydane po odwilży w 1957 r.), a Elżbieta Janicka obszerną, krytyczną rekonstrukcję komunikatów z broszury Marii Kann.

Trzeci tom zespołu Hopfinger jest być może najbardziej zróżnicowany; zamieszczono w nim analizy ",horyzontalne”, mapujące szersze pole, i „wertykalne” - sondujące konkretne zjawisko lub tekst kultury; czytelnika mogą zaskoczyć radykalne nieraz różnice tonów (od sprawozdawczego Ewy Koźmińskiej-Frejlak po prowokująco-sarkastyczny w retorycznie wyszlifowanej, energicznej filipice Elżbiety Janickiej) i rozmiarów tekstów (tekst Janickiej Świadkowie własnej sprawy... wyraźnie dominuje nad pozostałymi). Artykuły w Latach czterdziestych... odnoszą się często do utworów wspominanych w poprzednich tomach, a ponieważ kontynuują dowodzenie tej samej tezy, która padała w już opublikowanych książkach, czytelnik może odnieść wrażenie redundancji i nieustającego wewnętrznego echa w obrębie kolekcji. Tom ten jednak nie powinien być przeoczony. Jestem przekonana, że analiza lat tużpowojennych ma fundamentalne znaczenie dla zrozumienia obecnych zmian społecznych. Praca zespołu Maryli Hopfinger kieruje uwagę czytelników w obszar domagający się wielu wysiłków badawczych. Potrzeba wciąż pracy, by ujawniły się treści wczesnej prasy powojennej, publikowanej w językach polskim i jidysz, zawartość druków i wizualiów propagandowych, mowa plakatów ulicznych tamtego czasu, podręczników 
i sprawozdań sądowych. Stawką tych badań jest zrozumienie wspólnotowego procesu wyłaniania się z wojny, negocjowania jej znaczeń, sensów doświadczeń granicznych, wyniesionych z nich traum, dla których nie było jeszcze języka. Społeczeństwo Polski najdłużej w Europie „żyło w wojnie”, najwcześniej też - już w czasie okupacji - próbowało badać wojnę narzędziami nauk społecznych (myślę np. o grupie „Oneg Szabat”). W tym hipotetycznym zbiorze nieujawnionych jeszcze do końca informacji, jaki tu projektuję, rodzą się określenia dla masowego wymordowania Żydów Europy, których to terminów być może dziś już nie pamiętamy. To tu zaczyna się uwidaczniać proces racjonalizacji i detraumatyzacji doświadczeń - powstrzymany i zaprzepaszczony w narzuconym odgórnie dyskursie stalinizmu, zapomniany i nieodtworzony po 1956 r. Wielką zasługą autorów tomu jest wywołanie tego obszaru jako problemu badawczego nie tylko dla historyków, lecz także dla nauk o kulturze.

W omawianej serii książek zawierających pytania o polskiego „świadka” Zagłady z pełną ostrością zostają ujawnione praktyki, które „grupa większościowa” podejmuje, by usunąć z pola widzenia akty przekroczenia norm podzielanych przez nią przed wojną i podtrzymywanych po katastrofie wojny. Służą temu przede wszystkim wyciszenia, niedomówienia, oficjalne i prywatne kłamstwa, tworzenie obiektów przesłonowych, manipulacje przy tożsamości ofiar, selektywna uwaga. W trylogii „o świadku” podniesiono kilka fundamentalnych kwestii nierozwiązanych jeszcze $\mathrm{w}$ pełni $\mathrm{w}$ badaniach nad przeszłością polskiego społeczeństwa, takich jak przyczyny braku powojennej dyskredytacji antysemityzmu, trwałość rasistowskich uprzedzeń, nieustający wizerunkowy niepokój, retuszowanie niewygodnych treści i niezdolność przyjęcia urealnionej, nieheroicznej narracji historycznej. Trudno w tej sytuacji przecenić znaczenie społeczne tej interwencji; jest ona - podkreślę raz jeszcze - skierowana w centrum naszych dzisiejszych sporów, a w obliczu wymykania się dyskursów rasistowskich spod kontroli i ponownego ich instalowania się w przestrzeni publicznej stanowi istotny, aktywny sprzeciw wobec zachodzącej brutalizacji publicznych postaw i języków. Zdaniem coraz liczniejszej grupy badaczy tego rodzaju gest jest powinnością współczesnej, świadomej stawek, o jakie toczy się gra, tzw. humanistyki zaangażowanej.

Polemiczną energię i ostrość krytyki osiągnięto w omawianych tomach także dzięki zastosowaniu gestów i narzędzi, które w pewnej części mogą wywoływać dyskusję. Notuję poniżej główne potencjalne obiekcje, jakie może wzbudzić lektura „trylogii o świadku”. Po pierwsze, przyjęta teza o trwałym antysemickim komponencie polskiej kultury nie wyłania się z szeroko zakrojonych badań, ale jest aprioryczna i następnie uzasadniana dobrze dobranymi przykładami (rozumowanie redukcyjne odsłania się więc jako dedukcja pozostająca wciąż w ramach własnych założeń): proces toczy się przy wydanym z góry wyroku, gdy tymczasem można by sobie wyobrazić procedurę pełnego mapowania powojennej produkcji kulturalnej podejmującej tematy relacji polsko-żydowskich i budowanie argumentów metodą uśredniania danych, która zapewne doprowa- 
dziłaby do ujawnienia całej gamy postaw i pozwoliła oszacować, w jaki sposób i jak głęboko instaluje się wśród nich antysemityzm.

Po drugie, historycy - spodziewam się - będą się domagać bogatszego obudowania prezentowanych treści odniesieniami do dostępnych ustaleń rodem z nauk o przeszłości i studiów społecznych, wprowadzenia weryfikujących ujęć komparatystycznych i zestawień z grupami kontrolnymi, co pozwoliłoby wyjaśniać procesy oraz typować czynniki i zmienne prowadzące do antysemityzmu, niuansując $w$ ten sposób dowodzenie na temat tego, co stało się w Polsce „po przemocy"19. W kontrze do tego zarzutu trzeba podkreślić, że nie o niuansowanie w pracy zespołu Hopfinger jednak chodzi. Stawką jest raczej pobudzenie, sprowokowanie do poważnej, fundamentalnej rozmowy. Konfrontacyjne i krytyczne ujęcie, na które zdecydowali się autorzy projektu, łatwo uznać za uzasadnione w rodzimym kontekście, gdy, jak to się wielokrotnie okazywało, potrzebne są bardzo wyraziste stanowiska, by krytyka została usłyszana przez jej adresatów, i w sytuacji, gdy trud w y j a śn i a n i a zjawisk jest tak często przejmowany przez ewentualnych oburzonych wynikami badań i obracany w gest usprawi ed liwi a nia (przypadek np. Sprawiedliwych).

Dalej, pamięcioznawcy zapytaliby o to, jaką strategię pamiętania wystąpienie zespołu Hopfinger chce wspierać (zakładając, że działanie naukowe nie jest aktem społecznie neutralnym, lecz sprawczym). Oś konfliktu rekonstruowanego w tomach przebiega między ludnością polską (katolicką) a żydowską - Niemcy, a także inne społeczności: - Ukraińcy, Litwini, Łotysze, Austriacy, protestanci, grekokatolicy czy prawosławni, znikają z pola widzenia, pozostawiając Polaków twarzą w twarz z Żydami. Kulminację ta praktyka osiąga, gdy Tomasz Żukowski przypomina o przekształceniu motta Medalionów, jakie zaproponował w Prawdzie nieartystycznej Henryk Grynberg. Nie „Ludzie ludziom zgotowali ten los”, ale „ludzie - Żydom”. Badacz chce, byśmy tę sentencję przeczytali jeszcze odważniej. „«Ludzie» z motta Nałkowskiej to poddani opresji Żydzi i polska większość" ${ }^{20}$. Tomy wpisują się w ten sposób w tradycję „pamięci antagonistycznej”, identyfikowanej przez Annę Bull i Hansa Hansena jako typowa dla „pierwszego modernizmu", historycznie - pochodząca z początków wieku, dziś właściwa zwłaszcza dla środowisk konserwatywnych i ksenofobicznych, przywiązanych do idei narodu i wyrazistych gestów podziału. Morfologicznie więc świadomie antyrasistowskie wystąpienie zespołu Hopfinger niebezpiecznie zbliża się tym samym do zjawisk, które kontruje, przeciwstawiając się - jak rozumiem - zdyskredytowanym narracjom z liberalnego pola, łagodzącej, lecz nierozwiązującej konfliktów „pamięci kosmopolitycznej”21. Bezkompromisowa i radykalna posta-

${ }^{19}$ Prac komparatystycznych jest coraz więcej na rynku nauki światowej. Zob. np. Anna Cichopek-Gajraj, Beyond Violence: Jewish Survivors in Poland and Slovakia, 1944-48, Cambridge: Cambridge University Press, 2014.

${ }^{20}$ Tomasz Żukowski, Ekranizacje Medalionów [w:] Zagłada w „Medalionach”..., s. 246.

${ }^{21}$ Anna Bull, Hans Hansen, On agonistic memory, „Memory Studies” 2016, nr 9, s. 393. 
wa badaczy uczestniczących w projekcie o „polskim świadku” może się wydać czytelnikom pokrewna - skrytykowanej przecież już za perswazyjną nieskuteczność i swoiste instrumentalizowanie Zagłady (zob. np. Grzegorz Niziołek) „strategii wyizolowania jednego, przerażającego, szokującego obrazu, w którym polskie społeczeństwo miało się skonfrontować bez możliwości jakichkolwiek samousprawiedliwień. Jedyna dopuszczalna większa narracja dotyczyła, w tej wersji, polskiego antysemityzmu, przybierającego groźny kształt już przed wojną, w latach trzydziestych"22. Tymczasem rozwijane współcześnie badania nad polem przemocy - nie tylko nad „bystanders” - akcentują konieczność uwzględniania wielu zmiennych (obserwowania np. grup kontrolnych), skuteczność ujęć relacyjnych, porównawczych, potrzebę odtwarzania możliwie najszerszych i najbardziej szczegółowych społecznych ram przemocy, analizy wielokierunkowej i skontekstualizowanej (zob. nowe propozycje m.in. Mary Fulbrook, Christiny Moriny i Krijna Thijsa, Michaela Rothberga czy Eriki Lehrer ${ }^{23}$ ). Ujęcia konfrontacyjne, bilateralne wyraźnie odchodzą w przeszłość, skrytykowane za uproszczenia, esencjalizację i niską przydatność w rozeznawaniu głębokich uwarunkowań społecznych danego problemu i proponowaniu działań zaradczych.

Możliwe jest również sformułowanie pytań z pozycji kulturoznawstwa i antropologii literatury: polska kultura jest w tomach pod redakcją Hopfinger i Żukowskiego ujmowana preposteryjnie („,nasz ogląd osadzony jest we współczesnej kulturze, która po hekatombie Zagłady stawała się coraz bardziej świadoma własnych uprzedzeń" ${ }^{24}$ ) - (programowo) narzu cono więc jej historycznym przejawom współczesne normy i wartości, które nie mogły być spełnione osiem dekad wcześniej; działanie to niekoniecznie zaakceptowaliby historycy kultury. „Kultura” jest traktowana jako zjawisko pojedyncze i homogeniczne (czyli nie ma różnych, funkcjonujących równolegle do siebie polskich „kultur”) i definiowana tak, jak proponował w latach trzydziestych Stefan Czarnowski ${ }^{25}$, co każe zapytać o adekwatność ujęcia sprzed wstrząsu, jakim dla zjawisk społecznych była druga wojna światowa (a przecież konsekwencje tejże są obserwowane

${ }^{22}$ Grzegorz Niziołek, Polski teatr Zagłady, Warszawa: Wydawnictwo Krytyki Politycznej, 2014, s. 547.

${ }^{23}$ Mam na myśli następujące prace: Mary Fulbrook, Bystanders: Catchall concept, alluring alibi or crucial clue [w:] Probing the Limits of Categorization... Stanowisko redaktorów tego tomu zbiorowego: Christina Morina, Krin Thijs, Introduction: Probing the Limits of Categorization, artykuł dostępny online: https://www.berghahnbooks.com/downloads/intros/MorinaProbing_intro.pdf (dostęp 15 VII 2019); Michael Rothberg, The Implicated Subject: Beyond Victims and Perpetrators, Stanford: Stanford University Press, 2019; Erika Leher, From Heritage Communities to Communities of Implication, http://www.traces.polimi.it/2018/07/26/ from-heritage-communities-to-communities-of-implication/ (dostęp 15 VII 2019 r.).

${ }^{24}$ Maryla Hopfinger, Lata czterdzieste. Wprowadzenie..., s. 8.

${ }^{25}$ Zob. https://ibl.waw.pl/pl/o-instytucie/pracownie-i-zespoly/pracowniawspolczesnejliteraturyikomunikacjisp/seminarium-kategorie-opisu-zaglady-w-polsce-/seminarium-kategorie-opisu-zaglady-w-polsce (dostęp 10 VII 2019 r.). 
w tomach). Teza, że to antysemityzm lub antyjudaizm trwale definiują polską kulturę dowolnej epoki, przeczy podstawowemu dla antropologii założeniu kulturowej zmienności. Tomy są organizowane wokół konceptu „wzoru kultury”, skrótowo objaśnionego w projekcie seminarium, nierozwiniętego szerzej w publikacjach, podanego czytającym jako „pojęcie pierwotne”, tymczasem mającego konkretne pochodzenie, definicję, biografię, a także wielu przeciwników. Antropolog chciałby koniecznie się dowiedzieć, czy autorzy tomu rozumieją i stosują tę kategorię za jego kodyfikatorką antropolożką Ruth Benedict, która w Patterns of Culture (1934) zaproponowała owo pojęcie, wspierając stanowisko relatywizmu kulturowego (poglądu bez wątpienia niepodzielanego przez autorów). Gdyby zespół seminarium „Kategorie opisu Zagłady w Polsce” przyjął klasyczne rozumienie konceptu, cech tworzących polski wzór kultury byłoby więcej niż jedna (czyli niezmienny „źródłowy kod” antysemityzmu), gdyż Benedict zakładała identyfikowanie sieci kilku kategorii, które w dodatku były raczej możliwą do aktualizacji tendencją niż nienaruszalną stałą esencją danej kultury. Dalej, zgodne z duchem wczesnej antropologii wyodrębnienie cech "wzorcowych" nie pozwalałoby na krytykę, lecz jedynie na rozumiejący, wielostronny opis, wynikający z uwzględnienia wielu kontekstualnych danych (znów: relatywizm). Sposób dowodzenia prezentowany w warszawskich tomach nie wskazuje też na przyjęcie zrewidowanego pojęcia Benedict. Pomysł antropolożki krytykowano bowiem za statyczne ujęcie kultur, ignorowanie ich interakcji z kulturami sąsiednimi i skryte założenie ich rozdzielności (szczelnych granic). Zaproponowane przez badaczkę (komentowała trzy przykłady ludów Ameryki Północnej i Nowej Gwinei, notabene zaskakująco podobne w swych charakterystykach do opisów centralnych grup w triadzie Hilberga) narzędzie - ostrzegano - łatwo może być użyte $\mathrm{w}$ celach stereotypizacji, esencjalizacji i hierarchizacji społeczeństw ${ }^{26}$. Nieostre użycie klasycznego terminu w „trylogii o świadku” grozi możliwością takiego upraszczającego odbioru: zamiast złożonej rzeczywistości kulturowej wyłoni się z lektury stereotyp społeczny i jego jednowymiarowo opisany reprezentant - „fałszywy świadek” Zagłady.

Mimo tych pytań i wątpliwości tomy zespołu Instytutu Badań Literackich trzeba uznać za jedno z najambitniej zakrojonych działań w obrębie antropologii literatury, najdokładniej zrealizowanych, ze świadomie budowaną strategią poznawczą. Precyzyjny cel nadany tej pracy, interwencja w najbardziej nabrzmiały problem polskiego samookreślenia, czyni z omawianych publikacji ważną wypowiedź, niezbędną zwłaszcza dla tych, którzy angażują się na rzecz weryfikacji tutejszych kultur pamięci, zaciśniętych nadal w dławiący, nierozwiązany, miejmy nadzieję - rozwiązywalny, węzeł.

${ }^{26}$ Zob. zwięzły opis przedsięwzięcia Benedict i recepcję jej pomysłu np. w klasycznej pracy: James Peoples, Garrick A. Bailey, Humanity: An Introduction to Cultural Anthropology, Stamford: Cengage Learning, 2011, s. 77-78. 


\section{BIBLIOGRAFIA}

Bull Anna, Hansen Hans, On agonistic memory, „Memory Studies” 2016, nr 9.

Buryła Sławomir, Z perspektywy sprawców, ofiar i świadków, „Znak” 2007, nr 11.

Bystanders to the Holocaust, red. Michael R. Marrus, t. 1-3, Westport-London: Meckler, 1989 (seria „The Nazi Holocaust”, t. 8).

Cichopek-Gajraj Anna, Beyond Violence: Jewish Survivors in Poland and Slovakia, 1944-48, Cambridge: Cambridge University Press, 2014.

Fulbrook Mary, Bystanders: Catchall concept, alluring alibi or crucial clue [w:] Probing the Limits of Categorization. The bystander in Holocaust history, red. Christina Morina, Krijn Thijs, New York: Bergham Books, 2019.

Gross Jan Tomasz, Sprawcy, ofiary i inni, „Zagłada Żydów. Studia i Materiały” 2014, nr 10, t. 2. Hilberg Raul, Perpetrators, Victims, Bystanders: The Jewish Catastrophe, 1933-1945, New York: Aaron Asher Books, 1992; wyd. polskie: Sprawcy, ofiary, świadkowie. Zagłada Żydów 1933-1945, tłum. Jerzy Giebułtowski, Warszawa: Centrum Badań nad Zagładą Żydów i Wydawnictwo Cyklady, 2007.

Hopfinger Maryla, Lata czterdzieste. Wprowadzenie [w:] Lata czterdzieste. Początki polskiej narracji o Zagładzie, red. Maryla Hopfinger, Tomasz Żukowski, Warszawa: Instytut Badań Literackich PAN, 2019.

Hopfinger Maryla, Wszyscy jesteśmy świadkami. Zamiast wstępu [w:] Opowieść o niewinności. Kategoria świadka Zagłady w kulturze polskiej (1942-2015), red. Maryla Hopfinger, Tomasz Żukowski, Warszawa: Instytut Badań Literackich PAN, 2018.

Hopfinger Maryla, Zamiast wstępu [w:] Zagłada w „Medalionach” Zofii Nałkowskiej. Tekst i konteksty, red. Tomasz Żukowski, Warszawa: Instytut Badań Literackich PAN, 2016.

Janicka Elżbieta, Mord rytualny z aryjskiego paragrafu: o książce Jana Tomasza Grossa „Strach. Antysemityzm w Polsce tuż po wojnie. Historia moralnej zapaści”, „Kultura i Społeczeństwo" 2008, nr 2.

Janicka Elżbieta, Pamięć przyswojona. Koncepcja polskiego doświadczenia zagłady Żydów jako traumy zbiorowej $w$ świetle rewizji kategorii świadka, „Studia Litteraria Historica" 2014-2015, nr 3/4.

Janicka Elżbieta, Żukowski Tomasz, Ci nie sq z ojczyzny naszej, „Gazeta Wyborcza”, 7 V 2012, http://wyborcza.pl/magazyn/1,124059,11677718,Ci_nie_sa_z_ojczyzny_naszej.html.

Koprowska Karolina, Postronni? Zagłada w relacjach chłopskich świadków, Kraków: Universitas, 2018.

Lata czterdzieste. Poczq̨tki polskiej narracji o Zagładzie, red. Maryla Hopfinger, Tomasz Żukowski, Warszawa: Instytut Badań Literackich PAN, 2019.

Leher Erika, From Heritage Communities to Communities of Implication, http://www.traces.polimi.it/2018/07/26/from-heritage-communities-to-communities-of-implication/.

Morina Christina, Thijs Krin, Introduction: Probing the Limits of Categorization [w:] Probing the Limits of Categorization. The bystander in Holocaust history, red. Christina Morina, Krijn Thijs, New York: Bergham Books, 2019, https://www.berghahnbooks.com/downloads/intros/MorinaProbing_intro.pdf.

Nie-miejsca pamięci. Elementarz, red. Karina Jarzyńska, Maria Kobielska, Jakub Muchowski, Roma Sendyka, Aleksandra Szczepan, Kraków: Ośrodek Badań nad Kulturami Pamięci UJ, 2017.

Niziołek Grzegorz, Polski teatr Zagłady, Warszawa: Wydawnictwo Krytyki Politycznej, 2014. 
Opowieść o niewinności. Kategoria świadka Zagłady w kulturze polskiej (1942-2015), red. Maryla Hopfinger, Tomasz Żukowski, Warszawa: Instytut Badań Literackich PAN, 2018.

Peoples James, Bailey Garrick A., Humanity: An Introduction to Cultural Anthropology, Stamford: Cengage Learning, 2011.

Ringelblum Emanuel, Stosunki polsko-żydowskie w czasie drugiej wojny światowej. Uwagi i spostrzeżenia, oprac. Artur Eisenbach, Warszawa: Czytelnik, 1988 [nowe wydanie: Archiwum Ringelbluma. Konspiracyjne Archiwum Getta Warszawy, t. 29a: Pisma Emanuela Ringelbluma z bunkra, oprac. Eleonora Bergman, Tadeusz Epsztein, Magdalena Siek, Warszawa: ŻIH, 2018].

Rothberg Michael, The Implicated Subject: Beyond Victims and Perpetrators, Stanford: Stanford University Press, 2019.

Sendyka Roma, Bystanders as Visual Subjects: Onlookers, Spectators, Observers, Gawkers [w:] Probing the Limits of Categorization. The bystander in Holocaust history, red. Christina Morina, Krijn Thijs, New York: Bergham Books, 2019.

Sendyka Roma, Od obserwatorów do gapiów. Kategoria bystanders i analiza wizualna, „Teksty Drugie” 2018, nr 3.

Sendyka Roma, Od świadków do postronnych. Kategoria „bystander” i analiza podmiotów uwikłanych [w:] Świadek: jak się staje, czym jest?, red. Agnieszka Dauksza, Karolina Koprowska, Warszawa: Instytut Badań Literackich PAN, 2019.

Sendyka Roma, Poświadek, przeciw-postronny i (niczyja) trauma, „Widok. Teorie i praktyki kultury wizualnej" 2017, nr 18.

Zagłada w „Medalionach” Zofii Nałkowskiej. Tekst i konteksty, red. Tomasz Żukowski, Warszawa: Instytut Badań Literackich PAN, 2016.

Żukowski Tomasz, Archeologia nostalgiczna i archeologia krytyczna [w:] Opowieść o niewinności. Kategoria świadka Zagłady w kulturze polskiej (1942-2015), red. Maryla Hopfinger, Tomasz Żukowski, Warszawa: Instytut Badań Literackich PAN, 2018.

Żukowski Tomasz, Ekranizacje Medalionów [w:] Zagłada w „Medalionach” Zofii Nałkowskiej. Tekst i konteksty, red. Tomasz Żukowski, Warszawa: Instytut Badań Literackich PAN, 2016.

Żukowski Tomasz, Wielki retusz. Jak zapomnieliśmy, że Polacy zabijali Żydów, Warszawa: Wielka Litera, 2018.

\section{Strona internetowa}

https://ibl.waw.pl/pl/o-instytucie/pracownie-i-zespoly/pracowniawspolczesnejliteraturyikomunikacjisp/seminarium-kategorie-opisu-zaglady-w-polsce-/seminarium-kategorie-opisu-zaglady-w-polsce 